Dori Pavloska - Gjorgjieska, Ph.D ${ }^{1}$

MIT University, Faculty of Management,

Skopje, Macedonia

Jelena Stanojević, M.Sc ${ }^{2}$

University of Nis, Faculty of Science and Mathematics
SCIENTIFIC REVIEW ARTICLE

Received: October 27, 2014

Accepted: January 24, 2015

\title{
SUSTAINABILITY OF THE FOREIGN ASSISTANCE IN AGRICULTURE - MACEDONIAN EXPERIENCE
}

\begin{abstract}
Macedonian agriculture has received substantial donor support in the past two decades. Now, when most of those donor projects are completed, this paper looks at what have been the most important factors for achieving sustainability, and how the level of sustainability of the foreign assistance in the agriculture can be improved. The analysis is based on 8 different foreign donor projects in Macedonia. The data collection is done through a primary research - interviews with stakeholders of those projects, and secondary research - already existing publications on the topic. In the analyzed cases the achieved sustainability of the results is not on a required level. The factors that contributed to this can be seen in the lack of political support, socio-cultural aspects, institutional aspects, economic and financial aspects as well as the external factors. This gives basis for recommendations for the main stakeholders and potential users of this paper: the national government to ensure that the donors' country strategies are in line with the national strategies; to the donors to use the participatory approach in the project design; and to the beneficiaries (farmers) to take greater responsibility and commitment for ownership of the achieved project results.
\end{abstract}

Key words: Sustainability, agriculture, donor projects, foreign assistance, development.

JEL classification: F35, O13, O19

\section{ОДРЖИВОСТ СТРАНЕ ПОМОЋИ У ПОЉОПРИВРЕДИ - ИСКУСТВО МАКЕДОНИЈЕ}

\begin{abstract}
Апстракт
Македонска пољопривреда је примила значајну помоћ страних донатора у протекле две деценије. Сада, када је већина тих донаторских пројеката завриена, овај рад даје преглед најважнијих фактора за постизање одрживости стране помоћи пољопривреди, али и како степен те помоћи може бити одржан и унапређен. Анализа се базира на осам различитих страних донаторских пројеката у Македонији. Подаци су прикупљени путем примарног истраживања - интервјуа са стејкхолдерима тих пројеката, и

\footnotetext{
${ }^{1}$ dori.pavloska@mit.edu.mk

2 jelenastanojevic83@yahoo.com
} 
секундарног истраживања - путем већ постојеће литературе из конкретне области. У анализираним случајевима, постигнута одрживост није на жељеном нивоу. Фактори који су допринели таквом стағу су: недовољна политичка подршка, друштвено-културни аспекти, институционални, економски и финансијски аспекти, као и други екстерни фактори. Ово даје основу за препоруке које могу бити од изузетног значаја стејкхолдерима и потенцијалним корисницима овог рада: националној влади која треба осигурати да стратегије донаторских земаља буду у складу са националним стратегијама; донаторима који би требало да имају партиципативни приступ приликом дизајнирања пројеката; као и крајњим корисницима пројеката (пољопривредницима) који би требало да преузму већу одговорност и покажу већу посвећеност оствареним резултатима тих пројеката.

Кључне речи: одрживост, донаторски пројекти, страна помоћ, развој.

\section{Introduction}

After the independence of Macedonia in 1991 the slow and difficult transition process started. It was accompanied by decreased economic activity, increased unemployment, fall in the GDP and poverty expansion (SSO, 2011, p. 317) - all in the context of privatization of the state-owned companies, which was a long and non-transparent process.

Under these circumstances many foreign missions started activities for support of the country's development in different areas (SEI, 2005, p. 6). Big part of the support was directed in the agricultural sector, as one of the most important economic activities in Macedonia (SEI CDAD, 2011). Having in mind that agriculture contributes with $10 \%$ in the GDP (SSO, 2013, p. 333), its development is of essential importance for the general economic development.

From the perspective when most of the foreign donor projects in the agricultural sector in Macedonia are already finished, it is interesting to see:

- What are the results of the donor interventions in the agricultural sector in Macedonia?

- Have those results been locally integrated, further developed and sustained?

- What have been the factors influencing sustainability?

- How can sustainability of the donor projects in the agricultural sector be achieved?

\section{Theoretical review}

According to Danida (2006, p.47) "sustainability is a measurement showing if the benefit of the development intervention is likely to continue after the external assistance will be terminated". The evaluation of the sustainability refers to the effects of the development process on a long term. Sustainable development requires that in a long run social and ecological factors have to be taken into account in addition to economic 
factors in order to meet the present needs without compromising future generations (Merino, Vargas, Pastorino, \& Mazzon, 2014, p. 150).

In many ways the sustainability is a higher level of test checking if the development intervention has been successful or not. Too many development interventions tend to fail after the implementation phase is finished because either the target group or the responsible parties don't have the means or sufficient motivation to ensure the necessary resources for continuation of the activities. Sustainability becomes central topic in the evaluations because many development agencies are getting more focused on the longterm perspectives and the permanent improvements. As a result, capacity building of the communities and organizations is a common goal of the development interventions, consistent with the overall goal for promoting increased autonomy and independence of the partner countries in public service provision (Action Aid, 2005, p. 53).

Useful question for evaluation of the sustainability is the degree to which capacities have successfully developed, for example through participation, strengthening, ownership, availability of local resources, and political support. In addition, the sustainability of the development interventions depends heavily on checking if the positive impact justifies the necessary investments and if the community sufficiently appreciates the benefits so that it is ready to dedicate part of its limited resources in order to achieve it (Banerjee, 2007, p. 8).

Since the sustainability is connected to what happens after the development interventions are finished ideally it should be measured several years later. It is difficult to make a good evaluation of the sustainability while the activities are still ongoing or right after their ending. In that case the evaluation is based on projections for the future development based on the available knowledge for the intervention and the capacity of the involved parties to cope with the changeable conditions. That requires analysis of the context, its advantages and limitations as well as future scenarios.

The experience of the donor agencies shows that the sustainability of a development intervention depends on seven factors (Danida, 2006, p. 56):

- Measures of political support

- Technological choice

- Environment

- $\quad$ Socio-cultural aspects

- Institutional aspects

- Economic and financial aspects

- External factors.

Therefore, the interview questionnaire (Annex 2) that has been used contains questions that try to discover the relevant factors of the sustainability of the foreign assistance in the agricultural sector in Macedonia. Below the different factors are explained.

Measures of political support - Beneficiary's commitment is one of the most frequently identified factors, which influences the success of the development interventions. The commitment is expressed through agreeing on the objectives, and readiness to invest financial and human resources. The commitment of the beneficiary depends on the perception of the common interest, as opposed to the one in which the donor interest dominates (ActionAid, 2005, p. 38).

Choice of technology - The financial and institutional capacities of the partner country are the main determinants of the choice of technology. Thereby, one should take in consideration the effects of the technology in the society and the costs for acquiring and maintaining the technology versus its benefit (Danida 2007, p. 56). 
Environment - The importance of the environment is nowadays widely recognized. Even though the effects of the environment may seem non-significant on a short term, the wider effects may be significant on a long term. Therefore, one should always take in consideration the environmental policy, stimulations and regulatory measures, interests of the different stakeholders and effects of the development interventions (World Bank, 2007b, p. 41).

Socio-cultural aspects - The social and cultural factors influence the adaptability and relevance of the different development activities. They also influence the motivation of the members of the target group and whether they will participate and accept responsibilities in the development process (Lancaster, C., 2007, p. 15).

Development interventions that are consistent with the local traditions or do not require substantial changes in the way of behaving have greater chances for success.

Institutional aspects - The strength of the institutions and the capacity of the organizations are the most important success factors of the development interventions. For more details, one could analyze the management, administration system and beneficiaries' participation (Lancaster, C., Van Dusen, A., 2005, p. 18).

Economic and financial aspects - The evaluations should focus on three economic and financial aspects. First, the economic justification of the intervention. Second, the economic and financial benefit of the investment compared with the resources spent. Finally, financial sustainability of the operations in the future, researching if the assets are and will be sufficient to cover the future operations, maintenance and depreciation (Thiele R. et al, 2006, p. 2).

External factors - The development support takes place in a context of political, economic and cultural environment, which is outside of its control, but which can have critical influence on it. The factors such as: political stability, economic crisis, overall development level, the condition of the balance of payment, as well as natural disasters can have a key role for the sustainability of the development intervention (Riddell, R. S., 2014, p. 31).

\section{Hypotheses and research methods}

The purpose of this research is to analyze and determine the level of sustainability of the results of the foreign assistance in the agricultural sector in Macedonia. Based on those findings conclusions are drawn and recommendations made with the aim to define ways for increased level of sustainability of the foreign assistance in the agriculture. The recommendations refer to the main groups of stakeholders: donors, national authorities and farmers.

The paper starts from the following assumptions:

Ha. The donor interventions in the agricultural sector in Macedonia are relevant.

$\mathrm{Hb}$. The results of the donor interventions in the agricultural sector in Macedonia have been locally integrated, further developed and sustained.

Hc. Political support, institutional and economic aspects are factors influencing sustainability of the donor support in the agricultural sector in Macedonia.

$H d$. Donors, national authorities and farmers can improve the level of sustainability by working together.

This paper is drawing conclusions based on the analysis of 8 different foreign donor projects in the agricultural sector in Macedonia, and the sustainability of their results. 
The data collection is done through a primary research - interviews with stakeholders of those projects, and secondary research - already existing publications on the topic. The interviews were conducted with 17 stakeholders (former employees, beneficiaries of the foreign assistance in the agricultural sector, as well as experts in the area - in Annex 1) in the period September - October 2010 and October - November 2011.

\section{Research results}

The importance of agriculture in Macedonia can be seen from its substantial contribution in the Gross Domestic Product (2013: 9.6\%), (State Statistical Office, 2013 , p. 333). In addition it is important because around $43 \%$ of the population lives in the rural areas spread over $87 \%$ of the total surface of the country (National Strategy for Agriculture and Rural Development 2007 - 2013, p. 13). Agricultural employment serves as a social buffer, helping alleviate poverty and unemployment, particularly in times of high off-farm unemployment, which is particularly becoming severe in the time of the world economic crisis.

Macedonia has done very well in trade liberalization and important progress has been made in removing barriers for entry and exit trade. Macedonia is a signatory of the Central European Free Trade Agreement (CEFTA), and it is also a member of the World Trade Organization (WTO) (Vukotic and Spahn, 2013, p. 21). But market liberalization is one thing and to be able to successfully compete in it is another thing. Competitiveness is one of the major challenges with which the Macedonian agriculture is facing. If the producers fulfill the strict requirements on price and quality to compete in the EU markets their products will have access to the entire common market. But if they fail to meet these requirements they will quickly lose their market share in the domestic and regional markets and the sector production will decline.

According to the Central Donor Assistance Database (CDAD) of the Secretariat for European Issues of the Republic of Macedonia the foreign donors have invested around 360 million Euros from 1992 until 2011. It includes the Official Development Assistance (ODA) from the donor countries, as well as Other Official Flows (OOF). OOF are transactions that come from the official sector, but do not fulfill the criteria to be considered ODA since they are either not dedicated to development or they do not contain a grant element of at least 25\% (OECD, 2009, p. 180). Out of the total amount around $70 \%$ are development loans, and 30\% are grants. On 13 August 2011 there were total of 138 projects from the area of agriculture registered in CDAD, most of which EU funded projects (total of 63, from the programs CARDS, FARE, ECHO, Tempus, IPA), followed by Netherlands with 16 projects, Sweden with 13 projects, Germany with 7 projects, 5 projects each from World Bank, USA and Norway, 4 Japan and Taiwan, and the same number from the international multilateral donors Food and Agriculture Organization (FAO) and International Fund for Agricultural Development (IFAD).

The two biggest projects in this group cover $42 \%$ of the total investments. That is the building of the hydro-electric central Kozjak with Chinese funds and the Japanese assistance for building the hydro system Zletovica. It is clear that these projects have multipurpose, which is not only limited to the agricultural sector. Sill they are part of this group and impact the total amount of the foreign donor investments to a great extent. 
If the value of two more projects is added here (Rehabilitation and restructuring of the irrigation by the World Bank and the Dutch investment in the hydro system Lisice) then we come to the level of $54 \%$ of the total investment of thee foreign donors in the agricultural sector in Macedonia.

The investments of the foreign donors in the agricultural sector in Macedonia have been coming as multilateral and bilateral assistance. Multilateral projects are from the programs CARDS, FARE, ECHO, TEMPUS of the European Union as well as projects of the international organizations: World Bank, IFAD, FAO, United Nations Development Program (UNDP) and United Nations Industrial Development Organization (UNIDO). The bilateral assistance has been coming from: Japan, China, Netherlands, Sweden, USA, Germany, Taiwan, Italy, Switzerland, Norway and Turkey (SEI, CDAD 2011).

Japan, the international multilateral donors (primarily the World Bank) and China have assisted with significantly higher amounts compared to the other donors. But if we look at the structure of the assistance which has been provided by them it can be concluded that the they are actually creditors, which have supported Macedonia with favorable development loans.

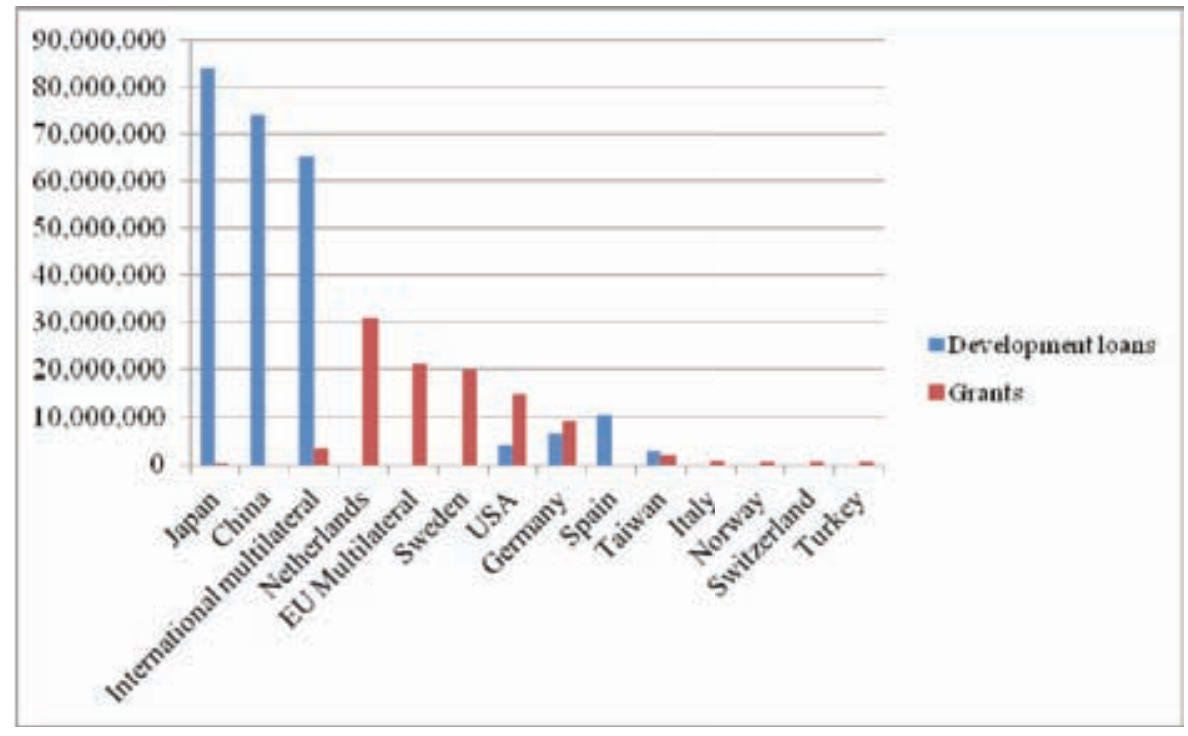

The structure of the foreign donor investments in the agricultural sector in Macedonia (in Euro), source: CDAD (www.sep.gov.mk), 13 August 2011

On average the projects in the agricultural sector in Macedonia have lasted for 27 months. $49 \%$ of the total value of the donor investments belong to project which started before $2000,47 \%$ to projects which started between 2000 and 2005, and only $4 \%$ of the total value belongs to projects that have started after 2005. This confirms the fact of withdrawing of especially the bilateral donors from Macedonia with its progress in the EU accession.

CDAD (SEI, 13 August 2011) divides the agricultural projects in several categories:

- Water resources in agriculture

- Agricultural financial services 
- Agricultural policy and administrative management

- Agricultural services

- Agricultural materials

- Agricultural associations and cooperatives

- Agricultural development

- Veterinarian services

- Agricultural education

- Agricultural research

- Livestock

- Agricultural protection

- Agricultural production

- Other

Thus categorized the biggest contribution (58.6\%) is from the projects from the category Water resources in agriculture. This is understandable is we take in consideration the infrastructural importance of these projects and the capital investments associated with them. They are followed by the Agricultural financial services (12.8\%), Agricultural policy and administrative management (8.6\%) and Agricultural services (5.5\%).

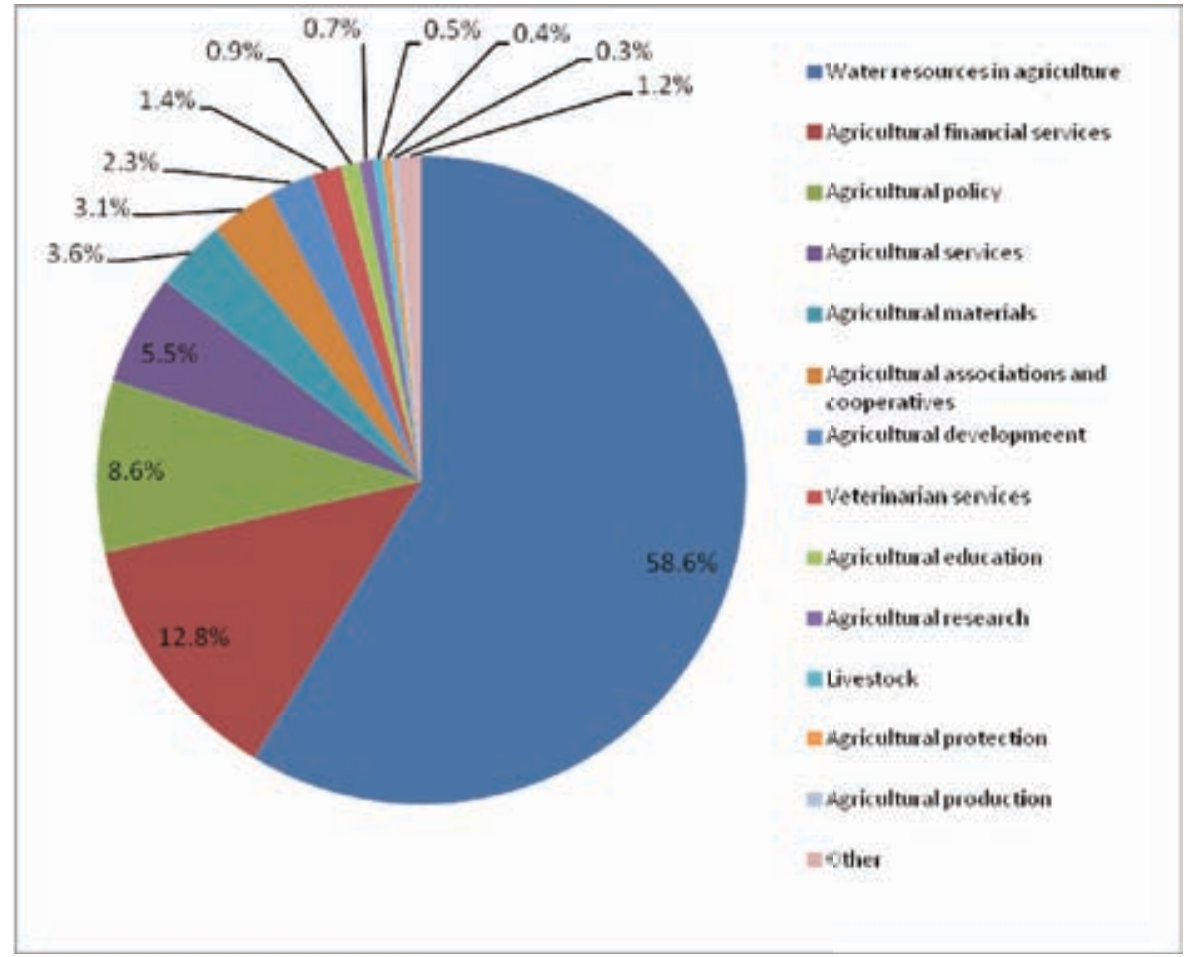

Participation of the different categories agricultural projects in the total amount of foreign donor investments in agriculture, source: CDAD (www.sep.gov.mk), 
Below is a presentation of the results achieved by 8 different foreign donor projects in the agricultural sector in Macedonia and their status after the end of those projects.

\section{Result - Improved efficiency of the irrigation system}

According to Dr. Ordan Cukaliev, professor in irrigation at the Faculty for agricultural sciences and food at the University Cyril and Methodius from Skopje (who has also been an active participant in many of the foreign donor projects in the area of irrigation), the capital investments are already made, but still very few of them have given a real effect in the agriculture. The project for building the hydro electric central Kozjak should be accompanied by an additional project for building a network for irrigation so that it will be made possible for the accumulated water to be used in the agriculture. The main purpose of the hydro system Zletovica is potable water supply, and the irrigation should be an additional benefit. That has still not been done. Irrigation Rehabilitation and Restructuring Project contributed towards improvement of the efficiency of the irrigation system in Macedonia, and it established and promoted the water communities as the management structures in the irrigation (World Bank, 2007a, p. 4). Previously, the managing responsibility was with the Public Enterprise for Water Economy. Based on the results from the primary research, the transfer of the management responsibility did not result in success due to the lack of expertise, equipment and finance of the water communities.

\section{Result - Institutional strengthening and adopting safe banking practices (with focus on agricultural support)}

Few years after the end of the Private Sector Development Project whose one of the aims was institutional strengthening and adopting safe banking practices (World Bank, 2003, p. 2) in six selected banks, the situation was such that most of the banks in the target group adopted improved policies and procedures for credit risk management, improved the information technology and the management information systems. Still, only two of the banks noted positive trends in their net profit, while one of the banks went bankrupt [http://www.kb.com.mk/, http://www.nlbtb.com.mk/, http://www.ob.com.mk/, http://www.stb.com.mk/, http://www.sparkasse.mk/].

\section{Result - Agricultural Credit Discount Fund}

The Agricultural Credit Discount Fund (ACDF) is a result of the IFAD program in Macedonia and now serves as a state-owned credit fund which provides favorable loans dedicated to individual agricultural producers and agribusiness (IFAD, 2010, p. 2). ACDF is administered and managed by an independent unit within the Ministry of Finance [http://www.finance.gov.mk/node/312].

The Agricultural credit discount fund (ACDF) is a responsible institution for administering of the revolving credit fund (Jovanovski and Nenovski 2006) formed by the credit lines IFAD1, IFAD2 and for support of the private sector from the World Bank PSDL1, PSDL2 and the credit line from the European Investment Bank in total amount of around 42 million Euro.

The main objective of the Agricultural credit discount fund if ensuring sustainable financial services in the agriculture, which are justified for the financial institutions, and 
at the same time acceptable for the farmers, as well as the small and medium enterprises, which are working on primary agricultural production, processing of agricultural products and export of primary agricultural products, as a target group.

\section{Result - Agricultural Investment Center}

This Center was supposed to be a result of the Project for Financial Services in Agriculture and IFAD2 (IFAD, 2010, p. 3). It was expected that advisors that worked for the project would establish a network of professionals which would have a key role in the agricultural and rural development. Unfortunately, based on the results from the primary research, due to financial problems the network was never established and the advisors started working as individual consultants (Dimitrov, L., interview 2011).

\section{Result - Development of the National Extension Agency}

Generally, the reforms of the National Extension Agency supported by the Macedonian Agricultural Advisory Support Program (MAASP) did not mark substantial success. The main reason for that was the status of the National Extension Agency (NEA) as a state agency, which was connected to the Ministry of Agriculture, Forestry and Water Supply (MAFWE), but not under its direct authority. Thus, the management of the NEA had a greater flexibility in its strategy and activities, and the success of the NEA depended greatly on the political will of the management, as well as the political pressures it faced. Also, the headquarters of NEA was in Bitola, which additionally decreased the communication of the related institutions whose headquarters were in the capital Skopje (Georgievski, P. interview 2011).

The Macedonian Agricultural Advisory Support Program planned that the National Extension Agency advisers should be certified and they should charge for their services via voucher system. Based on the results from the primary research, that plan was never implemented because of the existing practice of free public advisory services, as well as the informal government decision about the free public advisory services (Lambevska Domazetovska, V. interview 2011).

\section{Result - Quality Control Laboratory}

The Quality Control Laboratory was a result of the Macedonia Agribusiness Marketing Activity and was further supported by the Seal of Quality and Agribusiness Program. The Quality Control Laboratory was the first private independent laboratoty for quality control of the food. It was established as part of the Land O'Lakes Macedonia Agribusiness Marketing Activity (MAMA), financed by the United States Agency for International Development (USAID) in 1999, when the project started implementing the program for quality control of the meat and dairy products, though the Seal of Quality program.

The main activity of the Laboratory for Quality Control was providing technical support to the Seal of Quality program of the Association of Meat and Dairy Processors in Macedonia through trainings and regular testing. Thus it helped the food industry in satisfying the criteria for Good Production Practices, Hazard Analysis and Critical Control Points (HACCP) (Damovska, A. Interview 2010).

It was regulated by law that the export of food products was allowed with confirmation from an accredited laboratory. The efforts of the MAMA project and the 
Association of Meat and Dairy Processors for accreditation of the Laboratory were not successful. The explanations are mostly related to the monopoly in this area held by the Veterinarian Institute with the only accredited laboratory as part of it.

After the end of the projects the ownership of the laboratory was transferred to the Association of Meat and Dairy Processors the Association of former project employees. In the mean time the Laboratory was progressively decreasing its operations due to the low interest of the clients because of the missing accreditation of the laboratory. Based on the primary research results, in 2009 two of the members of the Association of the Meat and Dairy Processors bought the ownership stake from the Association of former employees, but that did not put the Laboratory back in business.

\section{Result - Seal of Quality}

The Seal of Quality was a result of the Macedonia Agribusiness Marketing Activity. It was a registered and protected trademark, which represented a certificate (unified and recognizable mark) awarded only to domestic meat and dairy products with checked and consistent quality. The Seal was awarded by the Association of the meat and dairy processors in Macedonia.

The Seal of Quality program in the Republic of Macedonia was conducted from December 1998. The design of the program was based on the results from the research of opinions of the consumers related to domestic meat and dairy products. The results showed that the consumers preferred the domestic products, as long as they were of confirmed and consistent quality. Based on this research the Association of Meat and Dairy Processors in Macedonia with technical, consulting and financial support from the MAMA project created the Seal of Quality program, justifying the trust by its consumers through high and consistent quality of its products.

Main objective of the Seal of Quality program was advancement of the meat and dairy industry through [http://www.znakzakvalitet.org.mk/defaultm.asp]:

- Improvement of the quality of the domestic meat and dairy products

- Building awareness and confidence in the quality of the products among the consumers

- Increase of the demand and sales of the domestic products compared to the imported products.

When the Seal of Quality Laboratory stopped its operations, the Seal of Quality program terminated its implementation. The consequences are evident. In 2001 during the promotional campaign for promotion of the Seal of Quality financed by the MAMA project (www.znakzakvalitet.org.mk/defaultm.asp):

- $\quad 84 \%$ of the consumers regularly used the products with the Seal of Quality in their meals;

- There was an 85\% level of awareness for the Seal of Quality;

- There was $70 \%$ level of recognition compared to other signs existing in the market

Currently, there are not any products with the Seal of Quality in the market any more (Kirovski, V. interview 2010). 


\section{Result - Federation of Farmers of the Republic of Macedonia}

The Federation of Farmers of the Republic of Macedonia (FFRM) was supported by the Support to Farmers Associations in the Republic of Macedonia (SFARM) project. Based on the primary research findings, systematic problems have been detected after the end of the project support, which influenced the efficiency and effectiveness of the organization. The main discovered problems were related to the involvement of the governance body into the operational issues, unrealistic strategic plan reflecting the effects of the operational planning, monitoring and implementation as well as the weak financial management system. The core business of the FFRM was seen to be intangible and therefore difficult to be sold. This is seen as an obstacle in achieving the financial sustainability.

\section{Interviews Findings}

The findings from the interviews are:

- Few of the achieved results of the foreign assistance in the agricultural sector in Macedonia sustained and integrated into the economy;

- In many cases there was a lack of commitment from the beneficiaries' side;

- There was also a low level of farmers' participation in the design and implementation of the projects;

- The level of farmers' organization has not been sufficiently high;

- There was a low level of interest among the beneficiaries for the long-term perspective of the achieved results;

- There was a lack of trust among the farmers, which is a prerequisite to strengthen the cooperation, improve the efficiency and provide sustainable results;

- Beneficiary organizations in many cases did not have sufficient capacity to ensure taking ownership of the results and achieving sustainability;

- Development interventions which have been connected to public institutions usually were easier to become sustainable.

\section{Discussion}

Thereby, a crucial issue for taking in consideration is the transfer of ownership of the achieved results, not only the material ownership, but moreover the insurance that the local beneficiaries will adopt the project results as their own and will take the responsibility for their further development. Unfortunately, in a big part of the projects the results are seen only until the project lasts, a short time after its ending (when the financial support ends) the activities of the local beneficiaries are terminated. Very few of the local beneficiaries managed to achieve sustainability of the achieved project results after the end of the project.

The reasons for that are different, but in big part are result of an insufficient political support, i.e. lack of commitment from the beneficiaries' side, but also the low level of their participation in the design and implementation of the projects. Another reason is the low level of interest among the beneficiaries for the long-term perspective of the achieved results. 
The socio-cultural aspects have also their role in the insufficient sustainability of the projects. One example of that is the lack of trust among the farmers, which would strengthen the cooperation, improve the efficiency and provide sustainable results.

The institutional aspects are among the most important reasons for the low level of sustainability. Development interventions which have been connected to public institutions usually are easier to become sustainable, as opposed to the ones related to the civil sector where the capacity is not yet fully developed and thus, does not enable sustainability of the results.

And when all of the above is taken in consideration, one comes to the issue of economic and financial aspects. Namely, in Macedonia, after its independence, the donors invested more than 360 million euro in the agricultural sector (SEI CDAD, 2011). The development interventions were relevant, but inefficient, effective, with some impact and with no significant results when it comes to sustainability. In that sense, it is logical to question the justification of those donors' investments.

In any case, one has to take in consideration the external factors, i.e. the political instability that even escalated into an armed conflict in 2001, as well as the transition period, which in a great extent influenced the entire development of the country.

\section{Conclusions and Recommendations}

It is a fact that agriculture is an important and priority economic activity in the national policy in Macedonia. In addition, the sector has received a substantial support from the foreign donors in all its components: public, private and civil sector. These are the main conclusions from this paper:

- The agricultural sector in Macedonia has not yet reached the necessary level of competitiveness, especially having in mind the EU integration aspirations of the country, which would mean entering a common market where only the best survive. Having in mind that the foreign donor investments have been directly or indirectly focused on improving the competitiveness of the Macedonian agriculture their relevance is obvious. In the upcoming period the domestic and foreign support to the agricultural sector is necessary;

- The exit strategies of many of the bilateral donors in Macedonia, expecting that the EU accession will happen soon, are premature. Due to the unresolved issue around the constitutional name of the Republic of Macedonia with the neighboring Greece, but also because of the EU expansion policy, the entry of Macedonia in EU is still very uncertain. Still, a great number of bilateral donors are withdrawing or have withdrawn from Macedonia, and in the mean time it has to rely on the pre-accession assistance, which cannot fully replace the one provided by the bilateral donors;

- $\quad$ Alignment of the donor strategies for the country with the national strategies is of a primary importance for achieving results. The general directions of the foreign donors in Macedonia have been generally aligned with the national ones, but not always with the same order of priorities. Thus, the projects that included components of support to the governmental institutions (especially assistance referring to meeting the requirements and criteria for 
EU membership) in a great extent achieved sustainability than those focused on support to the civil sector. That shows the low priority that the Macedonian government has been giving to the development of the civil sector, as opposed to the foreign donors who have been aware of the importance of the civil society for the overall development of the country;

- The success of the private sector is more visible and in a greater extent sustainable because of the recognition and taking over of the ownership. Part of the projects have given their support to the private entrepreneurs and depending on their vision, objectives and quality of the business plan and its implementation, and in a great extent on the entrepreneurial spirit of the beneficiaries, the sustainability of the results of those projects is greater;

- The activities of the foreign donors have not always been coordinated among themselves and with those of the governmental institutions. The Central Donor Assistance Database (CDAD) and the donor conferences organized by the Secretariat for European Issues (and supported by the United Nations Development Program) have been attempts for a better inter-donor coordination, but have not achieved full efficiency of the donor assistance;

- The over usage of expensive foreign human resources and expertise when it exists locally and is much cheaper in a great extent reduces the efficiency of the projects;

- Very little the donors have used the participatory approach during the design phase of their projects. The participatory approach would lead towards inclusion of the beneficiaries from the donor support in the starting idea of the project. Because of the lack of the participatory approach it has been very difficult to develop the sense of ownership and responsibility by the local beneficiaries and their commitment for further sustainable development of the results achieved by the foreign donor projects;

- During the implementation of the projects greater attention is placed on their effectiveness and achieving the short and medium-term objectives and less attention on the sustainability of their results on a long term. Thus, in a great extent the beneficiaries have been receiving the services and support from the projects for free without being made aware for their real market value. That has not prevented the achievement of the planned projects objectives, the activities have been implemented. However, it has in a great extent prevented the achievement of the sustainability after the end of the projects since the beneficiaries don't know the real market value of the products and services they are getting for free and they are not ready to pay for them once the projects end, since they have been receiving them for free for a long period of time;

- Some of the bilateral donors have withdrawn from Macedonia because of the progress in the EU accession of the country, but there are still some who are continuing the support. In any case, it is expected that the EU will be the main source of assistance in the agricultural sector in the coming period.

- The period of the greatest donor assistance in the agricultural sector is at the same time the period with constant decline of the arable land, livestock and increase of the poverty. The foreign donor investments did not succeed to 
eliminate the negative effects of the political immaturity and instability of the country, the bad privatization process, and the long period of transition.

From the analysis and discussion it can be concluded that in the analyzed cases from Macedonia the achieved sustainability of the results is not on a required level. The factors that contributed to this can be seen in the lack of political support, socio-cultural aspects, institutional aspects, economic and financial aspects as well as the external factors.

We can distinguish three different groups of stakeholders when it comes to foreign donor projects in the agricultural sector: government authorities, donors and farmers. Thus, the recommendations of this paper refer to them.

The government authorities should be proactive in cooperation with the foreign donors. It should have mechanisms which will ensure that the donors' country strategies are in line with the national strategies. In that way both, foreign donors and government authorities would work towards achieving the same objectives and building the capacities of the local beneficiaries (public, as well as private and civil society) as one of the conditions for achieving sustainability. By building the capacity of the beneficiaries the level of commitment and interest in the long-term perspectives will increase. The government should show a greater interest in taking the ownership of the results of the foreign donor missions, thus providing a good basis for achieving longterm sustainability.

The foreign donors should use the participatory approach in the project design. That means including the beneficiaries in the very early stage with the aim of better understanding of their needs, as well as the opportunities and development directions. The donors should accommodate to the local conditions and traditions in the country in order to achieve better commitment of the local beneficiaries. They should be more focused on the long-term sustainability of the achieved results. The key issue there, is the gradual transfer of ownership to the local beneficiaries (in the public, private or civil sector), which, if included in the process in time and to a sufficient extent, would be able to continue the started development and achieve sustainability of the results. At the same time, great focus should be given to the institutional capacity development in order to strengthen the beneficiary organization to the level that would ensure achieved sustainability after the end of the donor support.

The farmers should recognize the need for being organized, and thus cooperate, and be a pro-active partner to the donors and the government authorities. Building strong organizations will give them the necessary capacity to express their needs and interests, thus influencing the national and donor strategies in the agricultural sector. That will make them a relevant partner who should participate in projects design and implementation, and increase their level of commitment and responsibility of the sustainability of projects' results. The farmers must see themselves as an important factor who eventually takes ownership of the achieved results providing an institutional framework for them within farmers' organizations. 


\section{References}

ActionAid (2005). Real Aid, May 2005

Banerjee, V.A. (2007). Making Aid Work

DANIDA - Ministry of Foreign Affairs of Denmark (2006). Evaluation Guide, November 2006

Djankov et al (2005). The curse of aid, The World bank, April 2005

IFAD (2007). IFAD Strategic Framework 2007-2010

IFAD (2009). Rural Financing

IFAD (2010). An Ex-post Assessment of the Experience of the Agricultural Financial

Services Project (AFSP) in the Republic of Macedonia, March 2010

Hamilton, B.A. (2010). Kosovo Agricultural Opportunities

Lancaster, C. (2007). Foreign Aid

Lancaster, C., \& Van Dusen, A. (2005). Organizing Foreign Aid: Confronting the Challenges of the 21st Century. Brookings Institution Press.

Macedonia Agribusiness Marketing Activity - MAMA (2004). Final Report

Manning, R. (2006). Will "Emerging Donors" Change the Face of International Cooperation?, OECD DAC

Merino, M.H., Vargas, E.G.T., Pastorino, A.H., \& Mazzon, J.A. (2014). Validation of sustainable development practices scale using the Bayesian approach to item response theory, Tržište, Vol. XXVI, br. 2, str. 147 - 162.

Nitaj, F. (2012). Donor Coordination in Kosovo 2010 - 2020, American University of Kosovo and Rochester Institute of Technology

Paris Declaration on Aid Effectiveness, Feb-Mar 2005;

Secretariat for European Issues (SEI) of the Republic of Macedonia, (2011). Central Donor Assistance Database (CDAD), accessed in November 2011

Secretariat for European Issues (SEI) of the Republic of Macedonia, (2005). Donors in the Republic of Macedonia, December 2005

Sogge, D. (2002). Give and Take: What's the Matter with Foreign Aid? Zed Books

State Statistical Office (SSO) of the Republic of Macedonia (2011). Statistical Yearbook 2010

State Statistical Office (SSO) of the Republic of Macedonia (2013). Statistical Yearbook 2012

State Statistical Office (SSO) of the Republic of Macedonia (2013). Gross Domestic product 2011

Thiele R. et al (2006). Sectoral Aid Priorities: Are Donors Really Doing their Best to Achieve the Millennium Development Goals?, Kiel Institute for World Economics, January 2006.

Vukotić, N. C., \& Spahn, P.B. (2013). Outlook for Macroeconomic Development in the Western Balkans, Western Balkans Investment Framework, May 2013 
http://stats.oecd.org/glossary/search.asp, 20 May 2014

World Bank (2003). Report on the Complete Implementation of the Private Farmers Support Project, 10 March 2003

World Bank (2003). Report on the Completed Implementation of the Second Private Sector Development Project, June 2003

World Bank (2007a). Implementation Completion and Results Report, Irrigation Rehabilitation and Restructuring Project

World Bank (2007b). Integrating Environment into Agriculture and Forestry: Progress and Prospects in Eastern Europe and Central Asia - Volume II

World Bank (2007c). World Development Report 2008 - Agriculture for Development

\section{ANNEX 1 - LIST OF INTERVIEWEES}

1. Chukaliev, Ordan. [Professor on irrigation at the faculty for Agricultural Sciences and Food - Skopje] Interview. 30 November 2010

2. Damovska, Ana [Director of the Seal of Quality Program] Interview. 15 September 2010

3. Dimitrievska, Suzana [President of the Cooperative Demetra] Interview. 3 November 2011

4. Dimitrievski, Dragi [Dean of the Faculty of Agricultural Science and Food] Interview. 23 September 2010

5. Dimitrov, Lazo. [former Manager of the Agricultural Investment Center] Interview. 27 October 2010

6. Dimkovski, Trajan [Director of the Federation of Farmers of the RM] Interview. 26 October 2011

7. Dzartova-Petrovska, Biljana [Senior Development Cooperation Adviser] Interview. 21 November 2011

8. Gjorgjievski, Petar [employee of the MAASP project] Interview. 17 September 2010

9. Hadzievski, Vasko [Deputy Director of the AgBiz Program] Interview. 2 November 2011

10. Kiroski, Vladimir [Executive Secretary of the Association of Meat and Dairy Processors] Interview. 15 September 2010

11. Kosteska, Katerina [Deputy Minister of the Ministry of Economy of the RM], 31 October 2011

12. Kostov, Vasil [Director of the Livestock Institute of the RM] Interview. 11 November 2011

13. Lambevska Domazetovska, Vesela [employee of the MAASP project] Interview. 17 September 2010

14. Lundin, Sten-Rune [Director of the SFARM project] Interview. 20 September 2010 
15. Nikolovski, Aleksandar [President of Fagricom] Interview. 30 October 2011

16. Petrovski, Dejan [Manager of the First Grape-growers Cooperative] Interview. 10 November 2011

17. Shkrielj, Sanela [Project Coordinator of the Association for Local and Rural Development] Interview. 3 November 2011

\section{ANNEX 2 - INTERVIEW QUESTIONNAIRE}

1. What have been the results of the foreign assistance in the agriculture in which you have been involved (as an employee, beneficiary, expert or similar)?

2. Have those results sustained to date?

3. What have been the reasons for that?

4. How do you evaluate the beneficiary's commitment related to the foreign assistance in the agricultural sector in Macedonia?

5. Has the choice of technology influenced the sustainability of the foreign assistance in the agricultural sector in RM?

6. Has there been any environmental policy and regulatory measures that might influenced the sustainability of the foreign assistance in the agricultural sector in RM?

7. Has the foreign assistance in the sector been consistent with the local traditions? Do you think there have been any socio-cultural factors that could influence the sustainability?

8. Have the beneficiary organizations had the sufficient capacity (management, administration, HR and financial systems) to ensure sustainability?

9. Have the interventions been economically justified?

10. Have external factors (political, economic and cultural environment) influenced the sustainability? 